Molecules 2011, 16, 1389-1401; doi:10.3390/molecules16021389

OPEN ACCESS

molecules

ISSN 1420-3049

www.mdpi.com/journal/molecules

Article

\title{
New Hydrophilic/Lipophilic Tetra-a-(4-carboxyphenoxy) Phthalocyanine Zinc-Mediated Photodynamic Therapy Inhibits the Proliferation of Human Hepatocellular Carcinoma Bel-7402 Cells by Triggering Apoptosis and Arresting Cell Cycle
}

\author{
Chunhui Xia ${ }^{1,2}$, Yu Wang ${ }^{1}$, Wei Chen ${ }^{3}$, Wenxue Yu ${ }^{2}$, Baiqi Wang ${ }^{4}$ and Tao Li ${ }^{1, *}$ \\ 1 Basic Medicine Department, Qiqihar Medical College, Qiqihar 161006, China; \\ E-Mails: chunhuixia1969@sohu.com (C.X.); wyfr1970@sohu.com (Y.W.) \\ 2 College of Materials Science and Engineering, Jilin University, Changchun 130012, China; \\ E-Mail: slgwy@sohu.com (W.Y.) \\ 3 College of Chemistry and chemical Engineering, Qiqihar University, Qiqihar 161006, China; \\ E-Mail: chenwei150080@163.com (W.C.) \\ 4 School of Public Health, Tianjin Medical University, Tianjin 300070, China; \\ E-Mail: wbq1999@126.com (B.W.)
}

* Author to whom correspondence should be addressed; E-Mail: litao888@sohu.com;

Tel.: +86-452-2663899; Fax: +86-452-2663899.

Received: 5 January 2011; in revised form: 17 January 2011 / Accepted: 19 January 2011 /

Published: 7 February 2011

\begin{abstract}
Photodynamic therapy (PDT) is a novel and promising antitumor treatment. Phthalocyanine-mediated PDT has shown antitumor activity in some tumor cells, but the effect of new hydrophilic/lipophilic tetra- $\alpha$-(4-carboxyphenoxy)phthalocyanine zinc (TaPcZn)-mediated PDT (TaPcZn-PDT) on human hepatocellular carcinoma Bel-7402 cells and underlying mechanisms have not been clarified. In the present study, therefore, the ultraviolet-visible (UV-vis) absorption spectrum and cellular localization of TaPcZn, and effect of TaPcZn-PDT on the proliferation, apoptosis, cell cycle, Bcl-2 and Fas in Bel7402 cells were investigated by spectrophotometry, inverted microscope, 3-(4,5dimethylthiazol-2-yl)-2,5-diphenyl-tetrazolium bromide (MTT) assay, electron microscopy, annexinV-FITC/propidium iodide double staining, DNA content and immunoblot assay, respectively. We found that an intense absorption in UV-vis absorption spectrum of TaPcZn was in the red visible region at $650-680 \mathrm{~nm}$, where light penetration in tissue is efficient, that green $\mathrm{T} \alpha \mathrm{PcZn}$ localized to both plasma membrane and nuclear membrane of
\end{abstract}


Bel-7402 cells, signifying that there was a selective uptake of TaPcZn in Bel-7402 cells and TaPcZn-PDT would be expected to directly damage DNA, and that TaPcZn-PDT significantly resulted in the proliferation inhibition, apoptosis induction, $\mathrm{S}$ cell cycle arrest, and down-regulation of Bcl-2 and Fas. Taken together, we conclude that TaPcZn-PDT inhibits the proliferation of Bel-7402 cells by triggering apoptosis and arresting the cell cycle.

Keywords: tetra- $\alpha$-(4-carboxyphenoxy) phthalocyanine zinc; photodynamic therapy; human hepatoma Bel-7402 cells; proliferation; apoptosis; cell cycle

\section{Introduction}

Hepatocellular carcinoma is one of the most common malignant tumors in the world. Currently, the traditional therapies of surgery, chemotherapy and radiation therapy play an important role in the systemic treatment of hepatocellular carcinoma. However, the treatment outcome is generally poor. Thus, it is very important to find an effective alternative treatment for hepatocellular carcinoma.

Photodynamic therapy (PDT) is a novel and promising antitumor treatment in which photosensitizing drugs that are excited with an appropriate wavelength of light significantly result in photochemical destruction of tumors by yielding reactive oxygen species (ROS), such as singlet oxygen and free radicals [1-3]. Compared with traditional therapies, the outstanding advantage of PDT is that it destroys tumor through selective uptake of photosensitisers and precise application of the light with modern fiber-optic systems, and does not harm the normal surrounding tissues seriously.

Photosensitisers play a key role in PDT. At present, only a few porphyrin photosensitisers (Porfimer sodium, Talaporfin, Temoporfin, Verteporfin) are approved for the treatment of cancer in humans. Although these photosensitisers have demonstrated a wider spectrum of antitumor effects, they have various deficiencies that spur the development of better photosensitiser candidates [4,5]. As a result of the desirable electronic absorption and photophysical properties, phthalocyanines, containing a planar macrocycle with an $18 \pi$-electron system, are one of the most potential photosensitiser candidates [6,7]. Furthermore, inasmuch as hydrophilic group redounds to the transport of drug in the body and lipophilic group conduces to the uptake of drug in cancer cells, phthalocyanines with hydrophilic/lipophilic structure may become promising candidates for selective photosensitisers. Recently, accumulated evidences have demonstrated highly selective growth inhibitory effects of hydrophilic/lipophilic phthalocyanines-mediated PDT in a variety of cancer cells [8-10]. However, the effect of new hydrophilic/lipophilic tetra- $\alpha$-(4-carboxyphenoxy) phthalocyanine zinc (TaPcZn, Figure 1)-mediated PDT (TaPcZn-PDT) on human hepatocellular carcinoma Bel-7402 cells and underlying mechanisms have not been clarified.

Apoptosis or programmed cell death is a form of cell death in which a programmed sequence of events leads to the elimination of cells without releasing harmful substances into the surrounding area. Apoptosis plays a crucial role in developing and maintaining health by eliminating old cells,

unnecessary cells, and unhealthy cells $[11,12]$. Nowadays, a number of studies have shown that apoptosis is one key pathways in PDT process $[13,14]$. 
Figure 1. Chemical structure of TaPcZn.

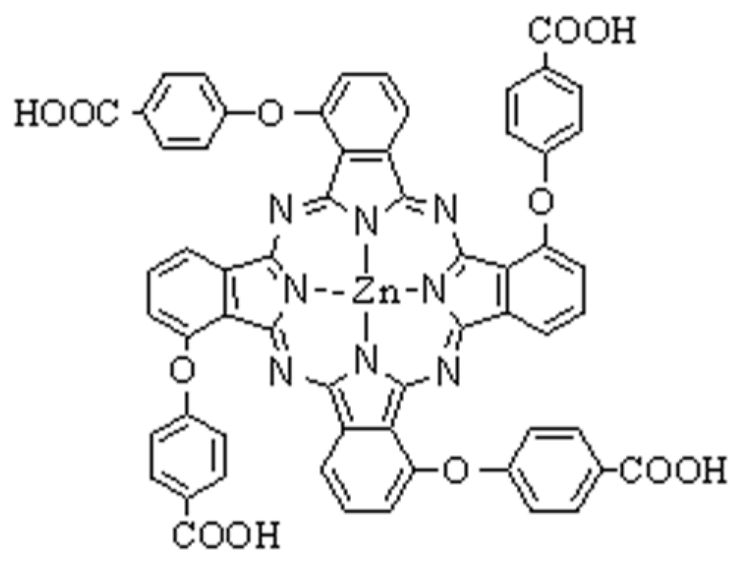

The cell cycle is the series of events that take place in a cell resulting in its division and duplication. It consists of four distinct phases: $G_{1}$ phase (pre-synthesis), $S$ phase (synthesis), $G_{2}$ phase (collectively known as interphase) and $\mathrm{M}$ phase (mitosis). The G0 phase is a quiescent period where cells have exited from the cell cycle and have stopped dividing. Activation of each phase relies on the proper progression and completion of the previous one. What with rapid and uncontrollable proliferation being one hallmark of cancer cell, arresting cancer cell cycle may offer therapeutic possibilities for treating malignant tumors. Accumulated evidence has demonstrated that cell cycle arrest leads to cell growth inhibition and/or apoptosis in PDT processes $[15,16]$.

In the present study, the objective of our study is to investigate whether hydrophilic/ lipophilic TaPcZn-PDT inhibits the proliferation of Bel-7402 cells by triggering apoptosis and arresting cell cycle. Based on an in vitro model, we found that TaPcZn-PDT inhibited proliferation and induced apoptosis in Bel-7402 cells, simultaneously arresting the cells at S phase with concomitant downregulation of Bcl-2 and Fas.

\section{Results and Discussion}

\subsection{Ultraviolet-visible absorption spectrum of TaPcZn}

An ideal photosensitizer should have a good absorption of tissue-penetrating red light. The ultraviolet-visible (UV-vis) absorption spectrum of TaPcZn in dimethyl sulfoxide (DMSO)/water mixtures showed an intense absorption in the red visible region at 650-680 nm (Figure 2). It is clear that, compared with the strong absorption of porphyrin photosensitisers such as Porfimer sodium $\left(\lambda_{\max \text { absorption }}=400 \mathrm{~nm}\right)$, Temoporfin $\left(\lambda_{\max \text { absorption }}=415 \mathrm{~nm}\right)$, and Talaporfin $\left(\lambda_{\max }\right.$ absorption $\left.=400 \mathrm{~nm}\right)$, TaPcZn exhibited an about $270 \mathrm{~nm}$ red-shifted absorption resulting in a better light penetration, higher PDT efficiency and lower skin phototoxicity [17,18]. Moreover, the electronic absorption spectra of T $\alpha$ PcZn can be readily interpreted using Gouterman's four orbital model [19]. Specifically, the intense absorption is attributed to the transition from the highest occupied molecular orbital to the lowest unoccupied molecular orbital. 
Figure 2. UV-vis absorption spectra of $\mathrm{T} \alpha \mathrm{PcZn}$ in $\mathrm{DMSO} /$ water $(1: 3, \mathrm{v} / \mathrm{v})$ mixtures.

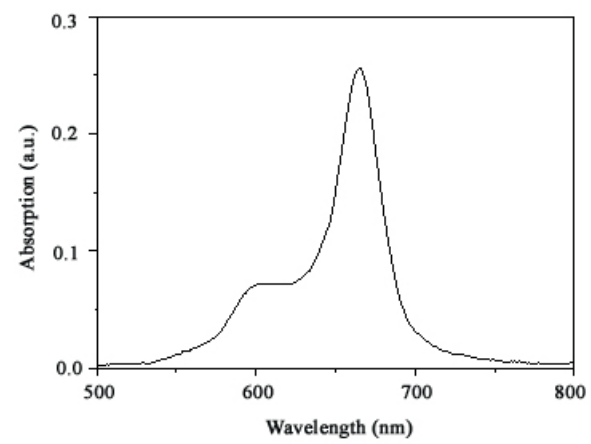

\subsection{Inhibitory effect of TaPcZn-PDT on the proliferation of Bel-7402 cells and human dermal fibroblasts}

From the biochemical aspect, an ideal photosensitizer should be non-toxic in the dark but after being exposed to light exhibit potent cytotoxic activity. Although a number of evidences have demonstrated that ideal phthalocyanine photosensitizers-mediated PDT can apparently inhibit proliferation in a variety of cancer cells [7-10,20-24], we firstly report the effect of hydrophilic/lipophilic TaPcZn-PDT on proliferation of Bel-7402 cells by the 3-(4,5-dimethylthiazol-2yl)-2,5-diphenyl-tetrazolium bromide (MTT) assay. As shown in Figure 3, the red light (600-700 nm)

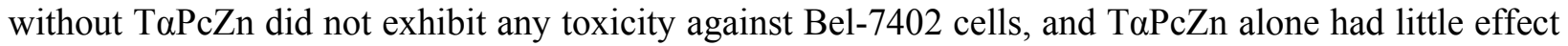
on the proliferation of Bel-7402 cells.

Figure 3. Effect of TaPcZn-PDT on the proliferation of Bel-7402 cells and HDFs. Proliferation of Bel-7402 cells and HDFs analyzed by MTT assay. Bel-7402 cells and HDFs were treated with the different concentrations of $\mathrm{T} \alpha \mathrm{PcZn}$ in the presence of red-light irradiation $\left(53.7 \mathrm{~J} / \mathrm{cm}^{2}\right)$. Cell viability was detected by MTT assay. $P<0.01$ versus the control value (cells treated with $0.1 \%$ DMSO).

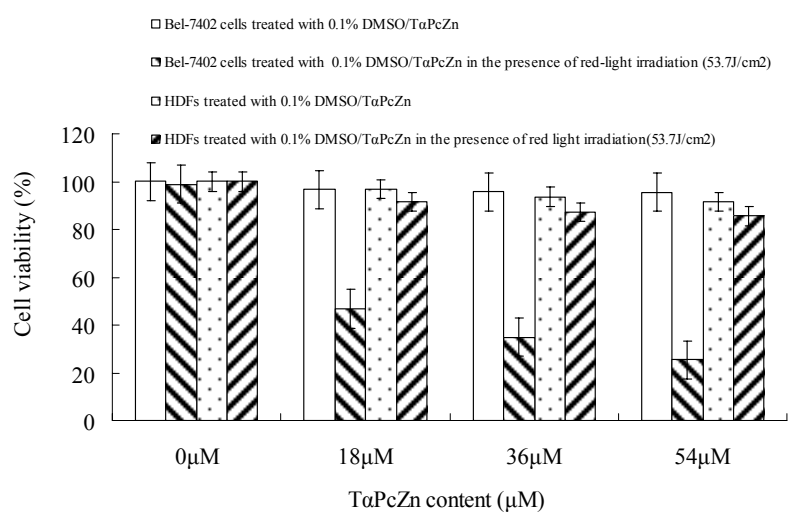

However, TaPcZn-PDT remarkably suppressed the proliferation of Bel-7402 cells in a dosedependent pattern, indicating that the combination of TaPcZn and red light irradiation can apparently inhibit the proliferation of Bel-7402 cells. The inhibition rate in Bel-7402 cells after TaPcZn-PDT treatment was significantly difference at $\mathrm{P}<0.01$ compared with the control cells. Furthermore, Figure 
3 also showed that TaPcZn-PDT had little effect on human dermal fibroblasts (HDFs), indicating that

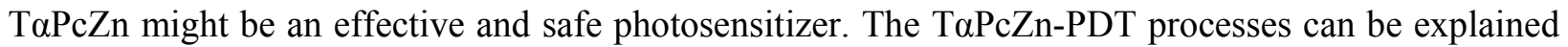
as follows [25]: (1) When irradiated with red light, TaPcZn absorbs energy and converts to a triplet state $\left({ }^{3} \mathrm{~T} \alpha \mathrm{PcZn}^{*}\right)$, a process known as intersystem crossing; (2) ${ }^{3} \mathrm{TaPcZn}{ }^{*}$ interacts with water and oxygen in its molecular oxygen $\left(\mathrm{O}_{2}\right)$ or triplet state $\left({ }^{3} \mathrm{O}_{2}\right)$ to generate $\mathrm{ROS}\left({ }^{1} \mathrm{O}_{2}, \mathrm{H}_{2} \mathrm{O}_{2}, \mathrm{OH}\right.$ and $\left.\cdot \mathrm{O}_{2}^{-}\right)$; (3) The generated ROS result in destruction of Bel-7402 cells. The processes described above can be expressed as follows:

$$
\begin{aligned}
& \mathrm{T} \alpha \mathrm{PcZn}+h \nu \stackrel{\text { Intersystem crossing }}{\longrightarrow}{ }^{3} \mathrm{~T} \alpha \mathrm{PcZn}^{*} \\
& { }^{3} \mathrm{~T} \alpha \mathrm{PcZn}^{*}+\mathrm{O}_{2}+\mathrm{H}_{2} \mathrm{O} \longrightarrow \mathrm{H}_{2} \mathrm{O}_{2}+\cdot \mathrm{OH}+\cdot \mathrm{O}_{2}^{-} \\
& { }^{3} \mathrm{~T} \alpha \mathrm{PcZn}^{*}+{ }^{3} \mathrm{O}_{2} \longrightarrow{ }^{1} \mathrm{O}_{2} \\
& \operatorname{ROS}\left(\mathrm{H}_{2} \mathrm{O}_{2}, \cdot \mathrm{OH}, \cdot \mathrm{O}_{2}^{-},{ }^{1} \mathrm{O}_{2}\right)+\text { Bel-7402 cells } \longrightarrow \text { Destruction of Bel-7402 cells }
\end{aligned}
$$

\subsection{TaPcZn cellular localization}

To further assess inhibitory effect of TaPcZn-PDT, T $\alpha \mathrm{PcZn}$ localization in Bel-7402 cells was detected by an inverted microscope. Previous studies suggested that phthalocyanine photosensitisers band to mitochondria, endoplasmic reticulum, and lysosomes [26,27]. The present inverted microscope assay showed that green TaPcZn selectively localized to both plasma membrane and nuclear membrane of Bel-7402 cells (Figure $4 \mathrm{~A}_{3}$ and Figure $4 \mathrm{~A}_{4}$ ), signifying that there was a selective uptake of TaPcZn in Bel-7402 cells and TaPcZn-PDT would be expected to directly damage DNA. In addition, it is clear that the hydrophilic carboxy/lipophilic phenyl structure led to the selective uptake of T $\alpha$ PcZn by Bel-7402 cells.

Figure 4. Effect of TaPcZn-PDT on Bel-7402 cells morphology. (A) Bel-7402 cells morphology analyzed by inverted microscope. Bars under each panel represent $50 \mathrm{um}$. (B) Bel-7402 cells morphology analyzed by Electron microscopy. Bars under each panel represent $500 \mathrm{~nm}$. Morphology assay in: panel $A_{1}$ or $B_{1}$, control Bel-7402 cells treated with $0.1 \%$ DMSO; panel $A_{2}$ or $B_{2}$, Bel-7402 cells treated with red-light irradiation $\left(53.7 \mathrm{~J} / \mathrm{cm}^{2}\right)$; panel $A_{3}$ or $B_{3}$, Bel-7402 cells treated with $54 \mu \mathrm{M}$ TaPcZn; and panel $A_{4}$ or $B_{4}$, Bel-7402 cells treated with $54 \mu \mathrm{M}$ TaPcZn in the presence of red-light irradiation $\left(53.7 \mathrm{~J} / \mathrm{cm}^{2}\right)$.

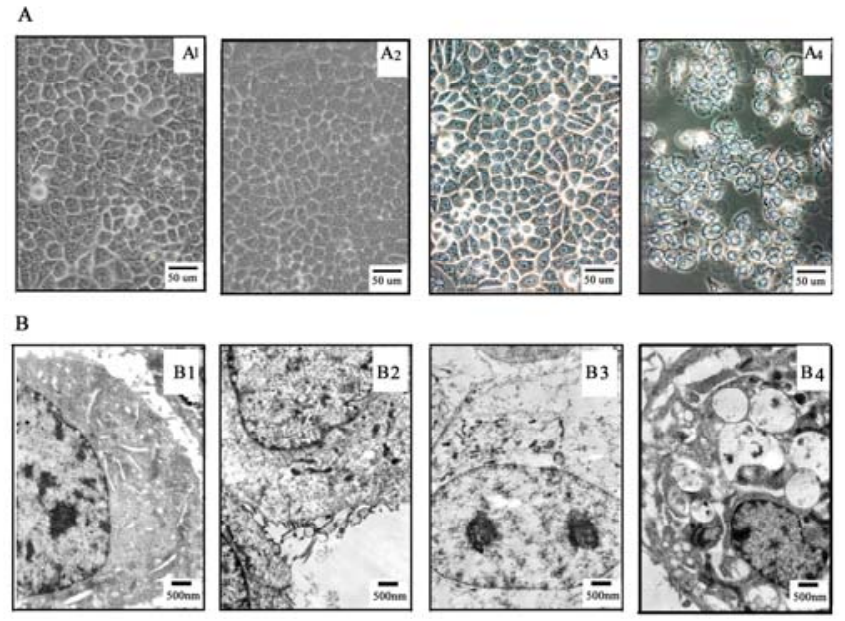




\subsection{Effect of TaPcZn-PDT on the apoptosis of Bel-7402 cells}

Accumulated evidences have suggested that phthalocyanines-mediated PDT can induce apoptosis in some cancer cells [22-25,28-30]. However, it is unclear whether T $\alpha \mathrm{PcZn}-\mathrm{PDT}$ can result in apoptosis of Bel-7402 cells. Therefore, in the present study, effect of TaPcZn-PDT on apoptosis of Bel-7402 cells was assayed by several ways. The morphological characteristics of apoptotic cell death were firstly detected by inverted microscope assay. Compared with control cells, light-treated cells and T $\alpha$ PcZn-treated cells, cells treated by T $\alpha$ PcZn-PDT apparently exhibited morphological characteristics of apoptotic cell death, such as cell shrinkage and extensive detachment of the cells from the cell culture substratum (Figure $4 \mathrm{~A}_{4}$ ). The occurrence of apoptosis was further assessed by electron microcopy assay. The results also showed that TaPcZn-PDT obviously led to morphological characteristics of apoptotic cell death, such as cell shrinkage, nucleus and cytoplasm fragment, chromatin condensation, cytosolic vacuolation and apoptotic bodies formation (Figure $4 \mathrm{~B}_{4}$ ). Furthermore, the apoptosis-eliciting effect of T $\alpha$ PcZn-PDT was quantitatively evaluated by flow cytometry analysis of annexin V-FITC/ propidium iodide (PI) double stained cells. Compared with the control treatment or light treatment alone, TaPcZn alone had little effect on the apoptosis of Bel-7402 cells (Figure 5). However, TaPcZn-PDT significantly led to the apoptosis of Bel-7402 cells in a dosedependent pattern (Figure 5), suggesting that the combination of TaPcZn and red light can apparently induce the apoptosis of Bel-7402 cells. Similar results were obtained by assaying sub-G DNA content $_{1}$ (Figure 6). All of the above results indicate that TaPcZn-PDT inhibits the proliferation of Bel-7402 cells by triggering apoptosis.

Figure 5. Effect of TaPcZn-PDT on the apoptosis of Bel-7402 cells assayed by flow cytometry analysis of Annexin V-FITC/PI double stained cells. Apoptosis assay in: panel $A$, control Bel-7402 cells treated with 0.1\% DMSO; panel B, Bel-7402 cells treated with red-light irradiation $\left(53.7 \mathrm{~J} / \mathrm{cm}^{2}\right)$; panel $C$, Bel-7402 cells treated with $54 \mu \mathrm{M} \mathrm{T \alpha PcZn}$; and panel $D \sim F$, Bel-7402 cells treated with $18,36,54 \mu \mathrm{M}$ TaPcZn in the presence of red-light irradiation $\left(53.7 \mathrm{~J} / \mathrm{cm}^{2}\right)$, respectively.
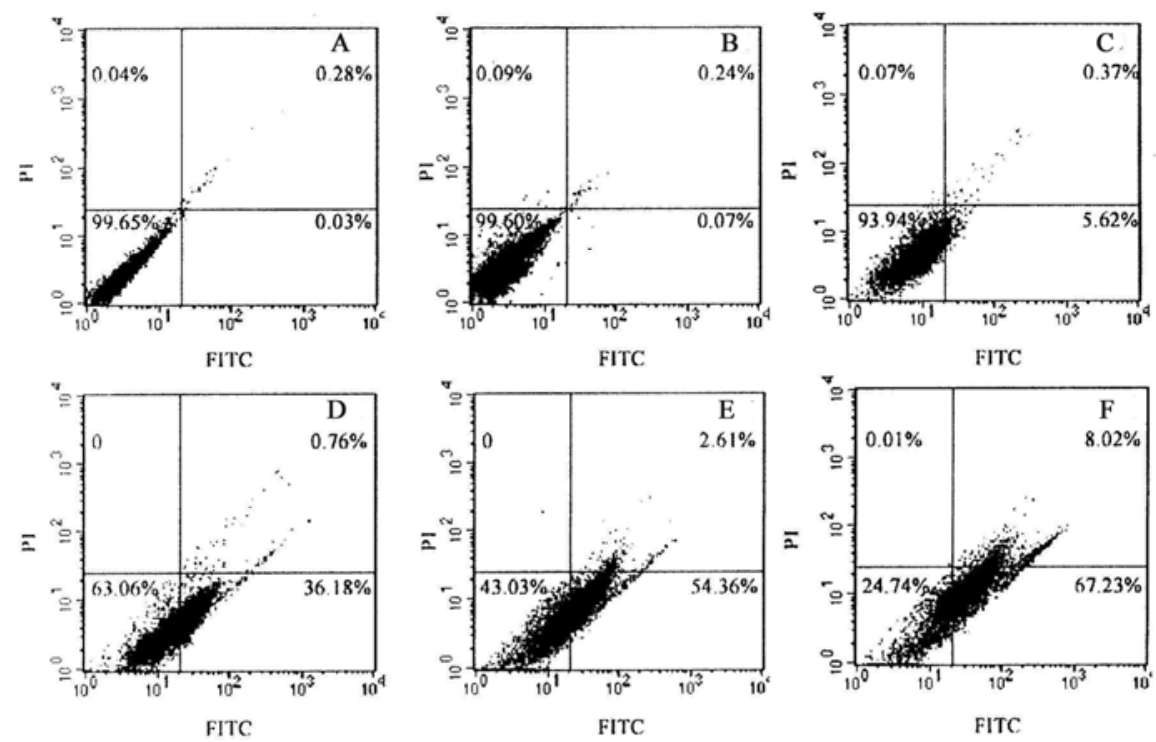


\subsection{Effect of TaPcZn-PDT on the cycle of Bel-7402 cells}

Accumulated results have demonstrated that phthalocyanines-mediated PDT can lead to cancer cell growth inhibition and/or apoptosis through G0/G1 or G2/M cell cycle arrest [22-24]. However, it is unclear whether TaPcZn-PDT can result in growth inhibition and/or apoptosis of Bel-7402 cell through arresting cell cycle. Therefore, in the present study, effect of T $\alpha$ PcZn-PDT on Bel-7402 cell cycle is investigated by DNA flow cytometry analysis. Compared with the control treatment, light treatment alone and TaPcZn treatment alone, TaPcZn-PDT apparently resulted in a decrease in the percentage of cells in G0/G1 and G2/M phase, and an increase in the percentage of cells in S phase (Figure 6), suggesting that TaPcZn-PDT arrested Bel-7402 cells at $\mathrm{S}$ phase and subsequently led to a decline in the percentage of cells in G2/M phase. Therefore, we conclude that TaPcZn-PDT inhibits the proliferation of Bel-7402 cell through $\mathrm{S}$ cell cycle arrest.

Figure 6. Effect of T $\alpha$ PcZn-PDT on the cycle and apoptosis of Bel-7402 cells assayed by flow cytometry analysis of DNA content. Assay of cycle and apoptosis in: panel A, control Bel-7402 cells treated with 0.1\% DMSO; panel B, Bel-7402 cells treated with red-light irradiation $\left(53.7 \mathrm{~J} / \mathrm{cm}^{2}\right)$; panel $C$, Bel-7402 cells treated with $54 \mu \mathrm{M}$ TaPcZn; and panel $D$, Bel-7402 cells treated with $54 \mu \mathrm{M} \mathrm{T \alpha PcZn}$ in the presence of red-light irradiation $\left(53.7 \mathrm{~J} / \mathrm{cm}^{2}\right)$.
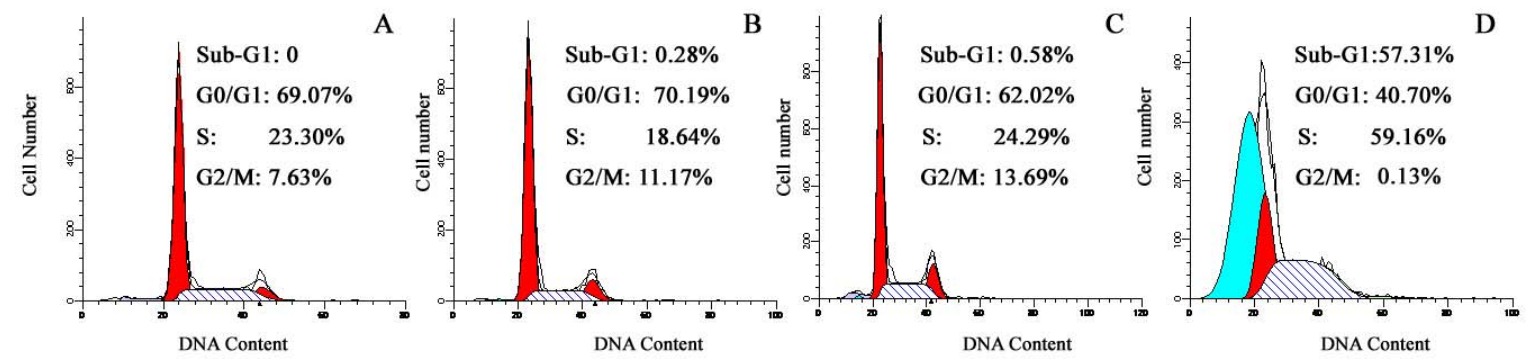

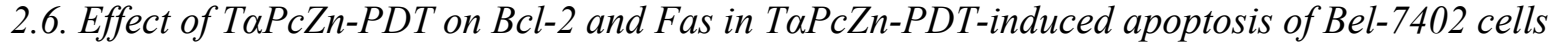

Bcl-2 is an anti-apoptotic protein. Fas is a 45-kD type II transmembrane receptor protein belonging to the tumor necrosis factor receptor family. Although Bcl-2 and Fas have been documented to play a crucial regulatory role in phthalocyanines-PDT-induced apoptosis [30-32], it is not clear whether Bcl-2 and Fas are involved in TaPcZn-PDT-induced apoptosis of Bel-7402 cells. Therefore, in the present study, effect of TaPcZn-PDT on Bcl-2 and Fas in TaPcZn-PDT-induced apoptosis of Bel-7402 cells is firstly investigated by Immunoblot assay. Compared with the control treatment, light treatment alone and TaPcZn treatment alone, TaPcZn-PDT dose-dependently led to down-regulation of Bcl-2 and Fas in TaPcZn-PDT-induced apoptosis of Bel-7402 cells (Figure 7), suggesting that Bcl-2 and Fas might modulate T $\alpha$ PcZn-PDT-induced apoptosis of Bel-7402 cells. 
Figure 7. Effect of TaPcZn-PDT on Bcl-2 and Fas respectively in TaPcZn-PDT-induced apoptosis of Bel-7402 cells analyzed by Immunoblot assay. Expression of Bcl-2 and Fas in: Lane 1, control Bel-7402 cells treated with 0.1\% DMSO; Lane 2, Bel-7402 cells treated with red-light irradiation $\left(53.7 \mathrm{~J} / \mathrm{cm}^{2}\right)$; Lane 3, Bel-7402 cells treated with $54 \mu \mathrm{M}$ TaPcZn; and Lane 4 6, Bel-7402 cells treated with 18, 36, $54 \mu \mathrm{M} \mathrm{T \alpha PcZn}$ in the presence of redlight irradiation $\left(53.7 \mathrm{~J} / \mathrm{cm}^{2}\right)$, respectively.

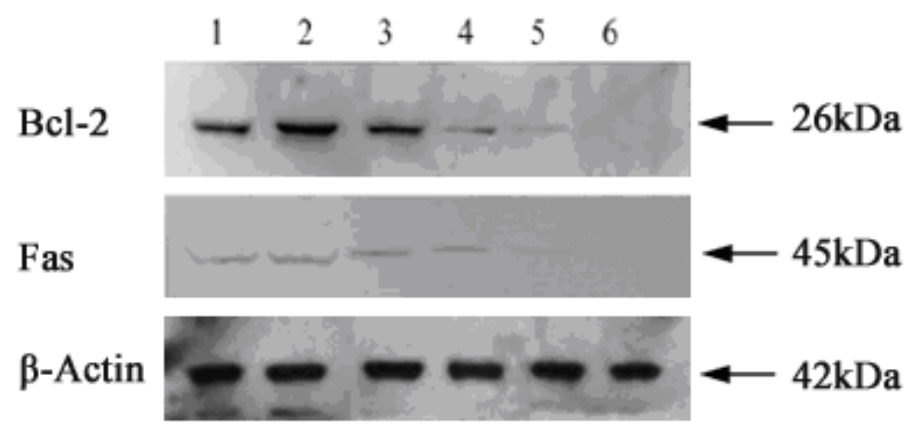

\section{Experimental Section}

\subsection{Materials}

Anti-Bcl-2 and anti-Fas antibodies were purchased from Santa Cruz Biotechnology (CA, USA). Annexin-V-FLUOS Staining Kit was purchased from Roche (Basel, Switzerland). Western blotting kit was purchased from Invitrogen (CA, USA). DMSO, MTT, PI, and RNAase were purchased from Sigma (St. Louis, MO, USA). RPMI-1640 medium was purchased from Gibco (CA, USA). Fetal bovine serum was purchased from PAA (Coelbe, Germany). Penicillin was purchased from Harbin Pharmaceutical Group (Heilongjiang, China). Streptomycin was purchased from Dalian Merro Pharmaceutical (Liaoning, China). Polyvinylidene difluoride membrane (PVDF) membrane was purchased from Amersham Pharmacia Biotech (Piscataway, NJ, USA). TaPcZn was synthesized as described in our previous report [33]. The TaPcZn stock solution was prepared in DMSO and stored at $4{ }^{\circ} \mathrm{C}$ in the dark. When used, the stock solution was appropriately diluted to obtain the desired concentration with a final DMSO concentration of $0.1 \%$. All other chemicals and reagents were of analytic grade.

\subsection{Ultraviolet-visible absorption spectrum assay}

UV-vis absorption spectrum of TaPcZn in DMSO/water (1:3, v/v) mixtures was assayed by UV2550 Spectrophotometer (Shimadzu, Kyoto, Japan).

\subsection{Cell culture}

Hepatocellular carcinoma Bel-7402 cells and HDFs were obtained from the Institute of Zoology, Chinese Academy of Science, China and cultured in RPMI-1640 medium supplemented with 10\% fetal bovine serum and $100 \mathrm{U} / \mathrm{mL}$ penicillin- $100 \mathrm{mg} / \mathrm{L}$ streptomycin in a humidified atmosphere of $5 \%$ $\mathrm{CO}_{2}$ at $37^{\circ} \mathrm{C}$. 


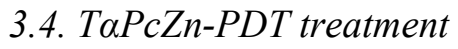

Bel-7402 cells and HDFs in logarithmic growth-phase were seeded in culture plates and incubated for $24 \mathrm{~h}$ in a humidified atmosphere of $5 \% \mathrm{CO}_{2}$ at $37{ }^{\circ} \mathrm{C}$. After being rinsed with phosphate-buffered saline, the cells were treated with TaPcZn stock solution diluted in medium for $2.5 \mathrm{~h}$ at $37{ }^{\circ} \mathrm{C}$ in the dark. Then the cells were irradiated for 15 min with a SS-B instrument (Wuxi Holyglow Physiotherapy Instrument Co., Ltd., Jiangsu, China) emitting red light within the wavelength range of 600 to $700 \mathrm{~nm}$. The light dose was $53.7 \mathrm{~J} / \mathrm{cm}^{2}$ at an irradiance of $59.7 \mathrm{~mW} / \mathrm{cm}^{2}$. Thereafter, cells were harvested at $8 \mathrm{~h}$.

\subsection{Cell viability assay}

Cell viability was determined by MTT assay [34]. At $8 \mathrm{~h}$ post TaPcZn-PDT of Bel-7402 cells and HDFs, $20 \mu \mathrm{L}$ of MTT working solution ( $5 \mathrm{mg} / \mathrm{mL}$ MTT in phosphate-buffered saline) was added in 96-well culture plates and incubated continuously at $37{ }^{\circ} \mathrm{C}$ for $4 \mathrm{~h}$. All mediums were removed from wells and replaced with $150 \mu \mathrm{L}$ of DMSO. After the blue-violet crystals were dissolved, the absorbance of each well was measured at $570 \mathrm{~nm}$ wavelength with a 680 microplate reader (Bio-Rad, CA, USA). The cell viability was calculated by the formula: cell viability = (absorbance of experimental wells/absorbance of control wells $) \times 100 \%$. Values are means \pm S.D. of three independent experiments.

\subsection{Inverted microscope and electron microscopy assay}

Following a 10.5-h incubation with $54 \mu \mathrm{M}$ TaPcZn, TaPcZn localization in Bel-7402 cells was assayed by an IX70 inverted microscope (Olympus, Tokyo, Japan). Furthermore, Bel-7402 cells at $8 \mathrm{~h}$ post T $\alpha$ PcZn-PDT were also detected by an inverted microscope. After Bel-7402 cells at 8 h post TaPcZn-PDT were fixed with $3 \%$ glutaraldehyde in sodium cacodylate buffer $(0.1 \mathrm{M})$, they were transferred to phosphate buffer $(0.1 \mathrm{M})$. The cells were then postfixed with $1 \%$ osmium tetroxide in $\mathrm{S}$ collidine. After gradient dehydration in ethanol and acetone, the cells were transferred to propylene oxide, and embedded in Epon 812. Semi thin sections were stained with $1 \%$ methylene blue. Thereafter, the sample was sectioned into ultrathin slices, contrasted with uranyl acetate and lead citrate, and observed under a JEM1200EX transmission electron microscope (JEOL, Tokyo, Japan)

\subsection{Flow cytometry analysis of Annexin V-FITC/PI double stained cells for apoptosis}

Confirmation of apoptosis was determined by measurement of externalized phosphatidylserine residues as detected using annexin V-FITC. The harvested Bel-7402 cells were collected and washed with ice-cold phosphate-buffered saline, and then suspended in $500 \mu \mathrm{L}$ of annexin V binding buffer $\mathrm{A}$. $100 \mu \mathrm{L}$ aliquot was taken, $2 \mu \mathrm{L}$ of annexin V-FITC and $2 \mu \mathrm{L}$ of PI were added, and the mixture was incubated for $5 \mathrm{~min}$ at room temperature in the dark. After the addition of $400 \mu \mathrm{L}$ of binding buffer, $1 \times 10^{4}$ cells were analyzed on a FACSCAN flow cytometer (Becton Dickinson, San Jose, CA, USA) by using cellquest software. The results are shown as a dotplot graph. In each graph, the percentages of apoptotic cells are indicated in lower right quadrant, the $Y$-axis corresponds to relative PI staining, and the $X$-axis corresponds to the log of the FITC signal. 


\subsection{DNA flow cytometry analysis for cell cycle and apoptosis}

The harvested Bel-7402 cells were washed twice in phosphate-buffered saline, fixed with 70\% icecold ethanol for $30 \mathrm{~min}$, washed twice with phosphate-buffered saline, and stained with PI (50 $\mu \mathrm{g} / \mathrm{mL})$ containing RNAase $(25 \mu \mathrm{g} / \mathrm{mL}$ ) for $30 \mathrm{~min}$. Cell cycle and apoptosis were assayed by DNA content on a flow cytometer.

\subsection{Immunoblot assay}

All immunoblots were performed using sodium dodecyl sulfate-polyacrylamide gel electrophoresis (SDS-PAGE) bis-Tris gel electrophoresis as outlined by the supplier. For total cellular protein, Bel7402 cells were lysed in buffer containing $25 \mathrm{mM}$ Hepes, $\mathrm{pH} 7.5,0.3 \mathrm{M} \mathrm{NaCl}, 1.5 \mathrm{mM} \mathrm{MgCl}, 0.2 \mathrm{mM}$ EDTA, $0.1 \%$ Triton X-100, $20 \mathrm{mM} \beta$-glycerophosphate, $0.5 \mathrm{mM}$ DTT, $1 \mathrm{mM}$ sodium orthovanadate, $0.1 \mu \mathrm{M}$ okadaic acid, and $1 \mathrm{mM}$ phenylmethylsulfonyl fluoride. Protein concentrations of the cell lysates were determined by lorry method with bovine serum albumin as standard, and the supernatants were boiled in SDS sample buffer for $5 \mathrm{~min}$. Equal amounts of lysate protein were run on 12\% SDSPAGE and electrophoretically transferred to PVDF membrane. After blocking, the blots were incubated with specific primary antibodies (anti-Bcl-2 and anti-Fas antibodies) overnight at $4{ }^{\circ} \mathrm{C}$ and further incubated for $1 \mathrm{~h}$ with horseradish peroxidase -conjugated respective secondary antibody. Bound antibodies were detected by enhanced chemiluminescence kit with a Lumino Image Analyzer (Founder, Beijing, China).

\subsection{Statistical analysis}

Values are means \pm S.D. of three independent experiments. Statistical significance was determined using Student's unpaired two-tailed $t$-test (SPSS 10.0 software). $P$ value less than 0.01 was statistically significant.

\section{Conclusions}

In the present study, we found that an intense absorption in UV-vis absorption spectrum of TaPcZn was in the red visible region at $650-680 \mathrm{~nm}$, that green TaPcZn localized to both plasma membrane and nuclear membrane of Bel-7402 cells, and that TaPcZn-PDT significantly resulted in the proliferation inhibition, apoptosis induction, S cell cycle arrest, and down-regulation of Bcl-2 and Fas. Taken together, we conclude that TaPcZn-PDT inhibits the proliferation of Bel-7402 cells by triggering apoptosis and arresting cell cycle.

\section{Acknowledgements}

This project was financial support by the Natural Science Foundation of Heilongjiang Province (No. D200822), the Scientific Research Foundation from the Health Department of Heilongjiang Province(No. 2005-333), the Scientific Research Foundation from the Education Department of Heilongjiang Province(No. 11511441), and the Scientific Research Foundation from Qiqihar (No.SFG06-02 and No. GY05-19). 


\section{References}

1. Douillard, S.; Olivier, D.; Patrice, T. In vitro and in vivo evaluation of radachlorin(R) sensitizer for photodynamic therapy. Photochem. Photobiol. Sci. 2009, 8, 405-413.

2. Xia, C.H.; Wang, B.Q.; Wang, Y.; Liu, Y.Q.; Xu, G.Y.; Wu, S. Damaging effects of nanosized $\mathrm{TiO}_{2}$ on bel-7402 human liver cancer cell under photoinduce. J. Inorg. Mater. 2006, 21, 1467-1471.

3. Lim, S.H.; Thivierge, C.; Nowak-Sliwinska, P.; Han, J.; van den Bergh, H.; Wagnières, G.; Burgess, K.; Lee, H.B. In vitro and in vivo photocytotoxicity of boron dipyrromethene derivatives for photodynamic therapy. J. Med. Chem. 2010, 53, 2865-2874.

4. Vallinayagam, R.; Weber, J.; Neier, R. Novel bioconjugates of aminolevulinic acid with vitamins. Org. Lett. 2008, 10, 4453-4455.

5. Gurba, P.; Vallinayagam, R.; Schmitt, F.; Furrer, J.; Juillerat-Jeanneret, L.; Neier, R. Novel bioconjugates of aminolevulinic acid with nucleosides. Synthesis 2008, 24, 3957-3962.

6. Longo, J.P.; Lozzi, S.P.; Simioni, A.R.; Morais, P.C.; Tedesco, A.C.; Azevedo, R.B. Photodynamic therapy with aluminum-chloro-phtalocyanine induces necrosis and vascular damage in mice tongue tumors. J. Photochem. Photobiol. B 2009, 94, 143-146.

7. Kolarova, H.; Nevrelova, P.; Bajgar, R.; Jirova, D.; Kejlova, K.; Strnad, M. In vitro photodynamic therapy on melanoma cell lines with phthalocyanine. Toxicol. In Vitro 2007, 21, 249-253.

8. Lo, P.C.; Leung, S.C.; Chan, E.Y.M.; Fong, W.P.; Ko, W.H.; Ng, D.K. Photodynamic effects of a novel series of silicon(IV) phthalocyanines against human colon adenocarcinoma cells. Photodiagn. Photodyn. Ther. 2007, 4, 117-123.

9. Liu, J.Y.; Lo, P.C.; Jiang, X.J.; Fong, W.P.; Ng, D.K. Synthesis and in vitro photodynamic activities of di-alpha-substituted zinc(ii) phthalocyanine derivatives. Dalton Trans. 2009, 21, 4129-4135.

10. Leung, S.C.; Lo, P.C; Ng, D.K.; Liu, W.K.; Fung, K.P.; Fong, W.P. Photodynamic activity of BAM-SiPc, an unsymmetrical bisamino silicon (IV) phthalocyanine, in tumour-bearing nude mice. Br. J. Pharmacol. 2008, 154, 4-12.

11. Szliszka, E.; Czuba, Z.P.; Domino, M.; Mazur, B.; Zydowicz, G.; Krol, W. Ethanolic extract of propolis (EEP) enhances the apoptosis- inducing potential of TRAIL in cancer cells. Molecules 2009, 14, 738-754.

12. Szliszka, E.; Czuba, Z.P; Mazur, B.; Paradysz, A.; Krol, W. Chalcones and dihydrochalcones augment trail-mediated apoptosis in prostate cancer cells. Molecules 2010, 15, 5336-5353.

13. Chiaviello, A.; Paciello, I.; Postiglione, I.; Crescenzi, E.; Palumbo, G. Combination of photodynamic therapy with aspirin in human-derived lung adenocarcinoma cells affects proteasome activity and induces apoptosis. Cell Proliferation 2010, 43, 480-493.

14. Otake, E.; Sakuma, S.; Torii, K.; Maeda, A.; Ohi, H.; Yano, S.; Morita, A. Effect and mechanism of a new photodynamic therapy with glycoconjugated fullerene. Photochem. Photobiol. 2010, 86, 1356-1363.

15. Awang, K.; Azmi, M.N.; Aun, L.I.; Aziz, A.N.; Ibrahim, H.; Nagoor, N.H. The apoptotic effect of 1 's-1'-acetoxychavicol acetate from alpinia conchigera on human cancer cells. Molecules 2010, $15,8048-8059$. 
16. Zeng, H. Selenium as an essential micronutrient, roles in cell cycle and apoptosis. Molecules 2009 , 14, 1263-1278.

17. Svaasand, L.O.; Ellingsen, R. Optical penetration in human intracranial tumors. Photochem. Photobiol. 1985, 41, 73-76.

18. Star, W.M. Light dosimetry in vivo. Phys. Med. Biol. 1997, 42, 763-787.

19. Gouterman, M. Spectra of porphyrins. J. Mol. Spectrosc. 1961, 6, 138-163.

20. Tapajós, E.C.; Longo, J.P.; Simioni, A.R.; Lacava, Z.G.; Santos, M.F.; Morais, P.C.; Tedesco, A.C.; Azevedo, R.B. In vitro photodynamic therapy on human oral keratinocytes using chloroaluminum-phthalocyanine. Oral Oncol. 2008, 44, 1073-1079.

21. Vittar, N.B.; Prucca, C.G.; Strassert, C.; Awruch, J.; Rivarola, V.A. Cellular inactivation and antitumor efficacy of a new zinc phthalocyanine with potential use in photodynamic therapy. Int. J. Biochem. Cell Biol. 2008, 40, 2192-2205.

22. Haywood-Small, S.L.; Vernon, D.I.; Griffiths, J.; Schofield, J.; Brown, S.B. Phthalocyaninemediated photodynamic therapy induces cell death and a G0/G1 cell cycle arrest in cervical cancer cells. Biochem. Biophys. Res. Commun. 2006, 339, 569-576.

23. Ahmad, N.; Feyes, D.K.; Agarwal, R.; Mukhtar, H. Photodynamic therapy results in induction of WAF1/CIP1/P21 leading to cell cycle arrest and apoptosis. Proc. Natl. Acad. Sci. 1998, 95, 6977-6982.

24. Gupta, S.; Dwarakanath, B.S.; Muralidhar, K.; Koru-Sengul, T.; Jain, V. Non-monotonic changes in clonogenic cell survival induced by disulphonated aluminum phthalocyanine photodynamic treatment in a human glioma cell line. J. Transl. Med. 2010, 8, 43.

25. Foote, C.S. Definition of type I and type II photosensitized oxidation. Photochem. Photobiol. 1991, 54, 659.

26. Lam, M.; Oleinick, N.L.; Nieminen, A.L. Photodynamic therapy-induced apoptosis in epidermoidcarcinoma cells. Reactive oxygen species and mitochondrial inner membrane permeabilization. J. Biol. Chem. 2001, 276, 47379-47386.

27. Quiogue, G.; Saggu, S.; Hung, H.I.; Kenney, M.E.; Oleinick, N.L.; Lemasters, J.J.; Nieminen, A.L. Signaling from lysosomes enhances mitochondria-mediated photodynamic therapy in cancer cells. Proc. Soc. Photo. Opt. Instrum. Eng. 2009, 7380, 1-8.

28. Rello-Varona, S.; Stockert, J.C.; Cañete, M.; Acedo, P.; Villanueva, A. Mitotic catastrophe induced in HeLa cells by photodynamic treatment with $\mathrm{Zn}(\mathrm{II})$-phthalocyanine. Int. J. Oncol. 2008, 32, 1189-1196.

29. Ahmad, N.; Gupta, S.; Feyes, D.K.; Mukhtar, H. Involvement of Fas (APO-1/CD-95) during photodynamic-therapy-mediated apoptosis in human epidermoid carcinoma A431 cells. J. Invest. Dermatol. 2000, 115, 1041-1046.

30. Lai, J.C.; Lo, P.C.; Ng, D.K.; Ko, W.H.; Leung, S.C.; Fung, K.P.; Fong, W.P. BAM-SiPc, a novel agent for photodynamic therapy, induces apoptosis in human hepatocarcinoma HepG2 cells by a direct mitochondrial action. Cancer Biol. Ther. 2006, 5, 413-418.

31. Usuda, J.; Chiu, S.M.; Murphy, E.S.; Lam, M.; Nieminen, A.L.; Oleinick, N.L. Domaindependent photodamage to Bcl-2. A membrane anchorage region is needed to form the target of phthalocyanine photosensitization. J. Biol. Chem. 2003, 278, 2021-2029. 
32. Miller, J.D.; Baron, E.D.; Scull, H.; Hsia, A.; Berlin, J.C.; McCormick, T.; Colussi, V.; Kenney, M.E.; Cooper, K.D.; Oleinick, N.L. Photodynamic therapy with the phthalocyanine photosensitizer Pc 4: the case experience with preclinical mechanistic and early clinicaltranslational studies. Toxicol. Appl. Pharmacol. 2007, 224, 290-299.

33. Wu, H.Y.; Chen, W.; Li, T.; Wang, Y.; Xia, C.H.; Li, X.L. Study on synthesis and antineoplastic activity of $\alpha$-tetra-(4-carboxyphenoxy)phthalocyanine zinc. J. Liaoning Norm. Univ. Nat. Sci. 2009, 32, 94-97.

34. Mosmann, T. Rapid colorimetric assay for cellular growth and survival, application to proliferation and cytotoxicity assays. J. Immunol. Methods 1983, 65, 55-63.

Sample Availability: Samples of T $\alpha \mathrm{PcZn}$ are available from the authors.

(C) 2011 by the authors; licensee MDPI, Basel, Switzerland. This article is an open access article distributed under the terms and conditions of the Creative Commons Attribution license (http://creativecommons.org/licenses/by/3.0/). 